\title{
Deoxyribonucleic Acid Relatedness Among Erwiniae and Other Enterobacteriaceae: the Soft-Rot Organisms (Genus Pectobacterium Waldee)
}

\author{
DON J. BRENNER, A. G. STEIGERWALT, G. V. MIKLOS, and G. R. FANNING
}

Division of Biochemistry, Walter Reed Army Institute of Research, Washington, D.C. 20012

\begin{abstract}
Relatedness among soft-rot-producing organisms of the genus Pectobacterium Waldee was assessed by means of interspecific deoxyribonucleic acid reassociation followed by chromatography on hydroxyapatite. Relatedness was also determined between pectobacteria and representatives from all other established genera of the family Enterobacteriaceae. The results indicate five distinct groups of pectobacteria: (i) Pectobacterium carotovorum (Jones) Waldee, including Erwinia aroideae (Townsend) Holland, E. atroseptica (van Hall) Jennison, E. solanisapra (Harrison) Holland, and Bacillus oleraceae Harrison; (ii) $P$. carnegieana (Lightle et al.) comb. nov.; (iii) cornstalk-rot bacterium and $P$. chrysanthemi (Burkholder et al.) comb. nov. (including $E$. dieffenbachiae McFadden, E. cytolytica Chester, and $P$. carotovorum f. sp. parthenii); (iv) $P$. cypripedii (Hori) comb, nov.; and (v) P. rhapontici (Millard) Patel and Kulkarni. Relatedness between groups of pectobacteria is 20 to $50 \%$ except between the $P$. carotovorum group and strains of $P$. carnegieana, which exhibit 60 to $70 \%$ relatedness. With few exceptions, the pectobacteria are 20 to $50 \%$ related to other members of the family Enterobacteriaceae. The data presented support the inclusion of pectobacteria in the family Enterobacteriaceae.
\end{abstract}

According to the latest edition of Bergey's Manual of Determinative Bacteriology (2), the genus Erwinia Winslow et al., as typified by $E$. amylovora, contains phytopathogens that cause wilts and blights as well as those that cause soft-rot diseases, the latter exemplified by $E$. carotovora. In addition to differences in the type of infection produced, the above-mentioned species exhibit significantly different biochemical characteristics. For these reasons, it has been repeatedly suggested that they be placed in separate genera, Erwinia and Pectobacterium Waldee, respectively $(13,17)$.

Two additional types of organism are cited in Bergey's Manual (2) as belonging to Erwinia: yellow-pigmented organisms $(E$. ananas, $E$. herbicola, etc.) that are often isolated from clinical sources (16) but that do not appear to be phytopathogenic (8) (it was recently recommended [11] that these organisms be placed in the genus Enterobacter as E. agglomerans), and a group of atypical erwiniae thought to be related to Klebsiella and Enterobacter (9).

We became interested in erwiniae as part of a continuing study of relatedness among members of the tamily Enterobacteriaceae (6).
Preliminary results indicated that the soft-rot erwiniae are significantly related to the other erwiniae and to organisms in other genera of Enterobacteriaceae. Nonetheless, extensive divergence is evident among species of Erwinia and between erwiniae and other Enterobacteriaceae. Our preliminary results were recently confirmed and extended by Gardner and Kado (12). These data $(6,12)$ and reawakened interest in erwiniae on the part of taxonomists, clinical microbiologists, and plant pathologists stimulated a thorough investigation of relatedness in erwiniae.

This report deals with deoxyribonucleic acid (DNA) relatedness in the organisms that produce soft-rot diseases.

\section{MATERIALS AND METHODS}

Organisms and media. The organisms used in this study are listed in Table 1 by the name under which they were received. The organisms were maintained on meat extract agar or brain heart infusion agar. Routine cultivation was carried out on brain heart infusion broth or nutrient broth on a dry-air rotary shaker. The incubation temperature was $30 \mathrm{C}$ for pectobacteria. 
TABLE 1. Bacterial strains used

\begin{tabular}{|c|c|c|c|}
\hline Organism received as & Source $^{a}$ & Organism received as & Source ${ }^{a}$ \\
\hline 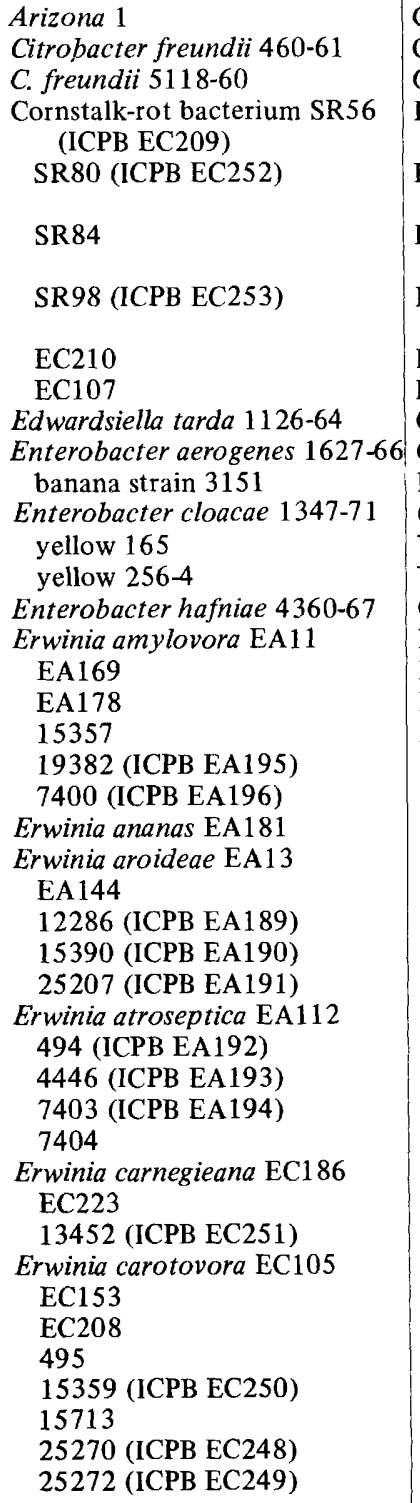 & $\begin{array}{l}\text { CDC } \\
\text { CDC } \\
\text { CDC } \\
\text { Kelman, Univ. } \\
\text { of Wisconsin } \\
\text { Kelman, Univ. } \\
\text { of Wisconsin } \\
\text { Kelman, Univ. } \\
\text { of Wisconsin } \\
\text { Kelman, Univ. } \\
\text { of Wisconsin } \\
\text { ICPB } \\
\text { ICPB } \\
\text { CDC } \\
\text { CDC } \\
\text { ICPB } \\
\text { CDC } \\
\text { V. J. Brenner, NIH } \\
\text { V. J. Brenner, NIH } \\
\text { CDC } \\
\text { ICPB } \\
\text { ICPB } \\
\text { ICPB } \\
\text { ATCC } \\
\text { ATCC } \\
\text { ATCC } \\
\text { ICPB } \\
\text { ICPB } \\
\text { ICPB } \\
\text { ATCC } \\
\text { ATCC } \\
\text { ATCC } \\
\text { ICPB } \\
\text { ATCC } \\
\text { ATCC } \\
\text { ATCC } \\
\text { ATCC } \\
\text { ICPB } \\
\text { ICPB } \\
\text { ATCC } \\
\text { ICPB } \\
\text { ICPB } \\
\text { ICPB } \\
\text { ATCC } \\
\text { ATCC } \\
\text { ATCC } \\
\text { ATCC } \\
\text { ATCC } \\
\text { ATC }\end{array}$ & 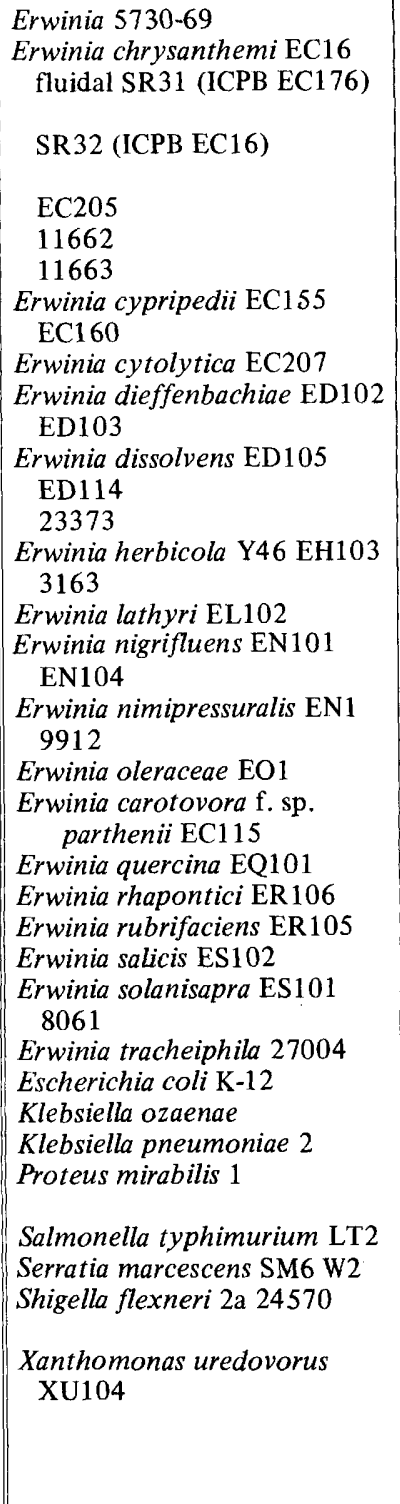 & $\begin{array}{l}\text { CDC } \\
\text { ICPB } \\
\text { Kelman, Univ. } \\
\text { of Wisconsin } \\
\text { Kelman, Univ. } \\
\text { of Wisconsin } \\
\text { ICPB } \\
\text { ATCC } \\
\text { ATCC } \\
\text { ICPB } \\
\text { ICPB } \\
\text { ICPB } \\
\text { ICPB } \\
\text { ICPB } \\
\text { ICPB } \\
\text { ICPB } \\
\text { ATCC } \\
\text { ICPB } \\
\text { ICPB } \\
\text { ICPB } \\
\text { ICPB } \\
\text { ICPB } \\
\text { ICPB } \\
\text { ATCC } \\
\text { ICPB } \\
\text { ICPB } \\
\text { ICPB } \\
\text { ICPB } \\
\text { ICPB } \\
\text { ICPB } \\
\text { ICPB } \\
\text { ATCC } \\
\text { ATCC } \\
\text { Univ. of Washington } \\
\text { CDC } \\
\text { CDC } \\
\text { Falkow, Univ. } \\
\text { of Washington } \\
\text { Theodore, NIH } \\
\text { WRAIR } \\
\text { Falkow, Univ. } \\
\text { of Washington } \\
\text { ICPB }\end{array}$ \\
\hline
\end{tabular}

${ }^{a}$ CDC, Center for Disease Control, Atlanta, Ga, from W. H. Ewing and G. Hermann; ICPB, International Collection of Phytopathogenic Bacteria, Univ. of California, Davis, from M. P. Starr; NIH, National Institutes of Health, Bethesda, Md; ATCC, American Type Culture Collection, Rockville, Md; WRAIR, Walter Reed Army Institute of Research, Washington, D.C. 
Erwinia amylovora and related organisms were grown at $23 \mathrm{C}$ to $25 \mathrm{C}$, and atypical erwiniae, members of Enterobacter agglomerans (Herbicola-Lathyri group), and all other Enterobacteriaceae were grown at $37 \mathrm{C}$. The medium used for labeling cells with ${ }^{32} \mathrm{PO}_{4}$ has been described previously (3).

DNA preparation. Both unlabeled and labeled DNA were prepared by a modification (3) of the method of Berns and Thomas (1). Cells were normally lysed by $0.5 \%$ sodium dodecyl sulfate (SDS) at $37 \mathrm{C}$ overnight. Certain erwiniae required lysozyme treatment for lysis. A few erwiniae apparently contain a potent deoxyribonuclease, as judged from rapid loss of DNA vicosity after cell lysis. In these strains, DNA was obtained by one of the following modifications in the lysing procedure: (i) shortening the SDS treatment to $1 \mathrm{~h}$ or less and immediately extracting the lysate with phenol; (ii) lysing the cells directly into phenol; or (iii) lysing cells as in (i) or (ii) at $75 \mathrm{C}$ for $15 \mathrm{~min}$ and then holding them at $37 \mathrm{C}$.

DNA reassociation. The conditions used for DNA reassociation and for the separation of DNA duplexes from unreacted single-stranded DNA on hydroxyapatite have been presented in detail elsewhere $(3,4,5)$. Essential reaction conditions are described below.

In all cases $0.1 \mu \mathrm{g}$ of sheared, ${ }^{32} \mathrm{PO}_{4}$-labeled DNA per $\mathrm{ml}$ was reacted with $150 \mu \mathrm{g}$ of sheared, unlabeled DNA per $\mathrm{ml}$ in $0.28 \mathrm{M}$ phosphate buffer (equimolar mixture of $\mathrm{Na}_{2} \mathrm{HPO}_{4}$ and $\mathrm{NaH}_{2} \mathrm{PO}_{4}, \mathrm{pH} \mathrm{6.8)} \mathrm{for} 16 \mathrm{~h}$. The temperature of incubation was 60 or $75 \mathrm{C}$. At 60 $C$, interspecific DNA reassociation is maximized yet specific, and is restricted to sequences with more than statistical-base-sequence similarity. At $75 \mathrm{C}$, reassociation is restricted to related sequences showing a high degree of thermal stability.

After incubation, the samples were diluted with distilled water to $0.14 \mathrm{M}$ phosphate buffer, and SDS was added to $0.4 \%$. The samples were then passed through hydroxyapatite, and unreacted DNA was eluted. The thermal stability of reassociated DNA was determined by washing the hydroxyapatite with 0.14 $M$ phosphate buffer at increasing temperature increments of $5.0 \mathrm{C}$. As the temperature exceeded the thermal stability of a class of DNA, the DNA was denatured and eluted from hydroxyapatite. When thermal stability was not of interest, the bound DNA was eluted from hydroxyapatite with $0.4 \mathrm{M}$ phosphate buffer.

The specific activity of the labeled DNA was between $8 \times 10^{4}$ and $1.5 \times 10^{5}$ counts per min per $\mu \mathrm{g}$. Ten samples were run simultaneously by using a batch procedure for thermal elution of DNA from hydroxyapatite (4). One homologous DNA reaction was included with each 10 samples. Observed homologous binding was arbitrarily designated $100 \%$. Reassociation of heterologous DNA reactions was determined relative to that of homologous DNA. Heterologous reactions were carried out three to four times at $60 \mathrm{C}$ and twice at $75 \mathrm{C}$.

\section{RESULTS AND DISCUSSION}

Bacterial relationships determined from DNA-DNA reassociation reactions are dependent upon the specificity and completeness of DNA reassociation and upon the ability to distinguish DNA duplexes from single-stranded DNA. In this and previous studies we have chosen $60 \mathrm{C}$ and $75 \mathrm{C}$ as incubation temperatures for DNA reassociation. At $60 \mathrm{C}$, we hope to detect all reasonably stable complementary sequences shared by the test organisms. At 75 C, only interspecies DNA duplexes with closely related or highly complementary polynucleotide sequences will be stable.

Assuming a common ancestor, relative reassociation at $60 \mathrm{C}$ indicates the amount of DNA from two organisms that is now related and how much DNA has diverged to a point where it can no longer form stable duplexes. The difference in thermal stability between homologous and heterologous DNA duplexes allows an approximation of divergence within related DNAs. We equate each $1 \mathrm{C}$ decrease in duplex thermal stability with approximately $1 \%$ unpaired bases within the duplex (14).

We use the name Pectobacterium or its vernacular equivalent, pectobacteria, to refer to the five species of soft-rot-producing Enterobacteriaceae recognized herein and to related organisms. To our knowledge, formal transfers to the genus Pectobacterium of three of the five species recognized have not been made. Therefore, on the basis of the morphological and biochemical characteristics previously reported for these three organisms $(7,13)$ and on the basis of the DNA similarities of these three species to each other and to other pectobacteria, as discussed below, the following new combinations are proposed: Pectobacterium carnegieana (Lightle et al.) comb. nov., $P$. chrysanthemi (Burkholder et al.) comb. nov., and $P$. cypripedii (Hori) comb. nov.

$P$. carotovorum (Jones) Waldee ATCC 495, $P$. cypripedii ICPB EC155, and $P$. carnegieana ICPB EC186 were the reference strains used to determine DNA relatedness among pectobacteria and relatedness between these organisms and the remainder of Enterobacteriaceae studied. Reactions using ${ }^{32} \mathrm{PO}_{4}$-labeled reference DNA from $P$. carotovorum ATCC 495 are shown in Table 2.

The six $P$. carotovorum strains tested at $60 \mathrm{C}$ show an average of $91 \%$ relatedness to ATCC strain 495 . The average $\Delta T_{m(e)}$ is $3.3 \mathrm{C}$, and relatedness remains high $(85 \%$ average $)$ when reassociation is carried out at $75 \mathrm{C}$. ATCC 15359 is least related to ATCC $495(80 \%)$ and exhibits a $\Delta T_{m(e)}$ of almost $7 \mathrm{C}$, yet $68 \%$ of the genomes of these strains form stable duplexes at $75 \mathrm{C}$.

$E$. atroseptica and $E$. aroideae strains exhibit an average $85 \%$ relatedness to ATCC 495 . There is evidence of some $4 \%$ unpaired bases in the related nucleotide sequences, and relatedness at $75 \mathrm{C}$ averages $84 \%$. The relatedness values for 
individual strains, with the exception of $E$. aroideae ATCC $12286(72 \%)$ and Erwinia sp. 5730-69 (74\%), are well within the range of relatedness observed between $P$. carotovorum strains. Erwinia sp. 5730-69, based on biochemical reactions, is classified as a typical Pectobacterium (W. H. Ewing, personal communication). Two strains of E. solanisapra and E. oleraceae ICPB EO 1 are also highly related to A TCC 495. Reassociation reactions among $P$. carotovorum strains and between ATCC 495 and strains of $E$. atroseptica, E. aroideae, $E$. solanisapra, and $E$. oleraceae form gaussian-type distributions with the mode between 90 and 99\% relatedness (Fig. 1 ). These distributions of relatedness are indicative of patterns seen previously only with strains of one species or of very closely related species (5).

Two of three strains of $P$. carnegieana are $60 \%$ related to ATCC 495. Approximately one-half of the related sequences are unstable in $75 \mathrm{C}$ incubations. The duplex stability indicates some $13 \%$ unpaired bases within related sequences. The third strain, $P$. carnegieana ATCC 13452 , exhibits about $40 \%$ relatedness to ATCC 495 with some $12 \%$ unpaired bases. About $25 \%$ relatedness is maintained at 75 C. $P$. carnegieana ATCC 13452 is not closely related to the other two $P$. carnegieana strains (Table 3). The distribution of relatedness of $P$. carnegieana strains to $P$. carotovorum ATCC 495 is midway between the relatedness shown by the $P$. carotovorum group of strains and that shown by all other pectobacteria that are considered below (Fig. 1).

DNA relatedness studies to be reported later (Brenner and Kelman, manuscript in preparation) show that cornstalk-rot bacteria and strains of $P$. chrysanthemi (as well as of $E$. dieffenbachiae, E. cytolytica, and $P$. carotovorum f. sp. parthenii) form a closely related group. These organisms are $40 \%$ related to $P$. carotovorum ATCC 495. Substantial divergence is present in related DNA sequences as shown both by the $\Delta T_{m(e)}$ of $17 \mathrm{C}$ and the fact that only $10 \%$ relative reassociation occurs at the more stringent $75 \mathrm{C}$ incubation temperature. Other pectobacteria tested for relatedness to ATCC 495 are $P$. cypripedii (29\% relatedness, $19 \%$ unpaired bases) and $P$. rhapontici (Millard, Patel and Kulkarni) (46\% relatedness, $16 \%$ unpaired bases).

Relatedness of $P$. carotovorum to species of Erwinia (Table 2) is from 24 to $56 \%$. Substantial divergence is present in all cases as judged by unpaired bases (11.5-19\%) and by the marked decrease in binding at $75 \mathrm{C}$. It appears that $P$. carotovorum is less diverged from $E$. nigrifluens, $E$. salicis, $E$. rubrifaciens, and perhaps $E$. quercina than from strains of $E$. amylovora and $E$. tracheiphila. In fact relatedness between $P$. carotovorum and $E$. nigrifluens is higher than that observed between $P$. carotovorum and all other pectobacteria except $P$. carnegieana.

Strains of the four yellow-pigmented organisms tested (E. ananas, E. lathyri, E. herbicola, and Xanthomonas uredovorus) are presumed, based on pigmentation and preliminary biochemical characterization, to be Enterobacter agglomerans. These organisms show an average of $32 \%$ relatedness to $P$. carotovorum with about $18 \%$ unpaired bases in the duplexed DNA. A similiar degree of relatedness exists between $P$. carotovorum and $E$. dissolvens and $E$. nimipressuralis, two atypical erwiniae.

$P$. carotovorum ATCC 495 shares one-fourth to one-third of its genome with species of Serratia, Citrobacter, Salmonella, Arizona, Escherichia, Enterobacter, and Shigella. This relatedness falls to an average of $6 \%$ at $75 \mathrm{C}$. $P$. carotovorum is least related to Edwardsiella tarda $(18 \%)$ and $P$. mirabilis $(11 \%)$.

Reassociation reactions at $60 \mathrm{C}$ established that $P$. cypripedii ICPB EC 155 and $P$. cypripedii ICPB EC160 are virtually identical based on relative DNA binding and duplex thermal stability (Table 4). Relatedness of $P$. cypripedii to other pectobacteria, species of Erwinia, and other Enterobacteriaceae is 21 to $42 \%$ with some 14 to $20 \%$ unpaired bases within the related nucleotide sequences. Reactions of ICPB EC155 are highest with DNA from the strains of Enterobacter agglomerans (E. herbicola and $X$. uredovorus) and perhaps lowest with strains of other species of Pectobacterium. In the main, ICPB EC155 exhibits a 25 to $33 \%$ core relatedness to strains belonging to other species of Enterobacteriaceae.

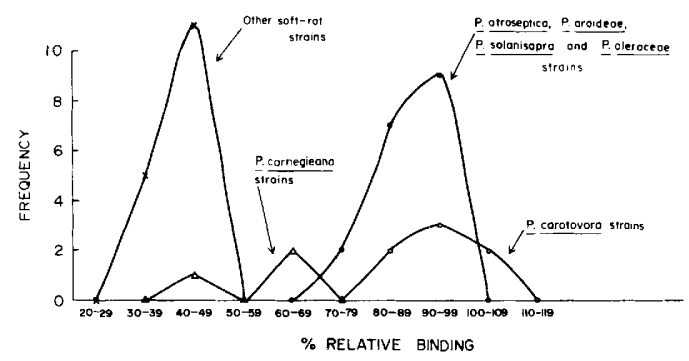

FIG. 1. Frequency distribution of relatedness between Pectobacterium carotovorum ATCC 495 and other pectobacteria. Values shown here were obtained from reactions at $60 \mathrm{C}$. The value for the reference strain, $P$. carotovorum ATCC 495, was inadvertently included. Therefore, the number of $P$. carotovorum strains that show 100 to $109 \%$ relative binding is one, not two. 
TABLE 2. Reassociation of DNA from Pectobacterium carotovorum 495

\begin{tabular}{|c|c|c|c|}
\hline Source of unlabeled DNA & $\begin{array}{l}\text { Relative binding } \\
\text { at } 60 \mathrm{C}(\%)\end{array}$ & $\begin{array}{l}\Delta T_{m(e)}{ }^{a} \\
\text { at } 60 \mathrm{C}\end{array}$ & $\begin{array}{l}\text { Relative binding } \\
\text { at } 75 \mathrm{C}(\%)\end{array}$ \\
\hline $\begin{array}{l}\text { Pectobacterium carotovorum ATCC } 495 \\
\text { ICPB EC } 208 \\
\text { ICPB EC105 } \\
\text { ATCC } 25270 \\
\text { ATCC } 15713 \\
\text { ATCC } 25272 \\
\text { ATCC } 15359\end{array}$ & $\begin{array}{r}100 \\
104 \\
94 \\
91 \\
90 \\
84 \\
80\end{array}$ & $\begin{array}{l}0.4 \\
2.1 \\
4.0 \\
3.0 \\
3.5 \\
6.7\end{array}$ & $\begin{array}{r}100 \\
102 \\
92 \\
84 \\
84 \\
79 \\
68\end{array}$ \\
\hline Average & 91 & 3.3 & 84 \\
\hline $\begin{array}{l}\text { Erwinia atroseptica ATCC } 7403 \\
\text { ATCC } 7404 \\
\text { ATCC } 494 \\
\text { ATCC } 4446 \\
\text { ICPB EA } 112 \\
\text { E. aroideae ATCC } 25207 \\
\text { ICPB EA } 144 \\
\text { ATCC } 15390 \\
\text { ICPB EA13 } \\
\text { ATCC } 12286 \\
\text { Pectobacterium } 5730-69\end{array}$ & $\begin{array}{l}96 \\
92 \\
90 \\
90 \\
83 \\
87 \\
87 \\
86 \\
83 \\
72 \\
74\end{array}$ & $\begin{array}{l}1.0 \\
1.1 \\
1.7 \\
1.5 \\
7.5 \\
3.6 \\
4.8 \\
3.5 \\
6.4 \\
6.6 \\
4.7\end{array}$ & $\begin{array}{l}94 \\
84 \\
90 \\
85 \\
71 \\
84 \\
81 \\
82 \\
72 \\
72 \\
68\end{array}$ \\
\hline Average & 85 & 3.9 & 80 \\
\hline $\begin{array}{l}\text { Erwinia solanisapra ICPB ES101 } \\
\text { ATCC } 8061 \\
\text { Bacillus oleraceae ICPB EO1 }\end{array}$ & $\begin{array}{l}99 \\
71 \\
94\end{array}$ & $\begin{array}{l}0.3 \\
8.0 \\
1.0\end{array}$ & $\begin{array}{r}104 \\
60 \\
93\end{array}$ \\
\hline Average & 88 & 3.1 & 86 \\
\hline $\begin{array}{l}\text { Erwinia amylovora ICPB EA } 169 \\
\text { ATCC } 15357 \\
\text { ATCC } 19382 \\
\text { ICPB EA11 } \\
\text { E. tracheiphila ATCC } 27004\end{array}$ & $\begin{array}{l}37 \\
30 \\
28 \\
24 \\
25\end{array}$ & $\begin{array}{l}17.5 \\
18.0 \\
18.1 \\
17.2 \\
18.8\end{array}$ & $\begin{array}{r}10 \\
4 \\
5 \\
6 \\
3\end{array}$ \\
\hline Average & 29 & $\overline{17.9}$ & 6 \\
\hline $\begin{array}{l}\text { E. nigrifluens ICPB EN104 } \\
\text { E. salicis ICPB ES102 } \\
\text { E. rubrifaciens ICPB ER } 105 \\
\text { E. quercina ICPB EQ101 }\end{array}$ & $\begin{array}{l}56 \\
49 \\
48 \\
42\end{array}$ & $\begin{array}{l}11.5 \\
16.5 \\
15.4 \\
12.3\end{array}$ & $\begin{array}{l}32 \\
17 \\
17 \\
24\end{array}$ \\
\hline Average & 49 & $\overline{13.9}$ & 23 \\
\hline $\begin{array}{l}\text { E. ananas ECPB EA } 181 \\
\text { E. herbicola ICPB } 3163 \\
\text { E. lathyri ICPB EL } 102 \\
\text { Xanthomonas uredovorus ICPB XU104 }\end{array}$ & $\begin{array}{l}37 \\
33 \\
32 \\
26\end{array}$ & $\begin{array}{l}16.5 \\
17.8 \\
17.3 \\
18.2\end{array}$ & $\begin{array}{l}7 \\
5 \\
6 \\
5\end{array}$ \\
\hline Average & 32 & $\overline{17.5}$ & 6 \\
\hline $\begin{array}{l}\text { Erwinia nimipressuralis ICPB EN1 } \\
\text { E. dissolvens ICPB ED105 }\end{array}$ & $\begin{array}{r}34 \\
32 \\
\end{array}$ & $\begin{array}{l}15.4 \\
16.8 \\
\end{array}$ & $\begin{array}{r}11 \\
7 \\
\end{array}$ \\
\hline Average & 33 & 16.1 & 9 \\
\hline
\end{tabular}


TABLE 2-Continued

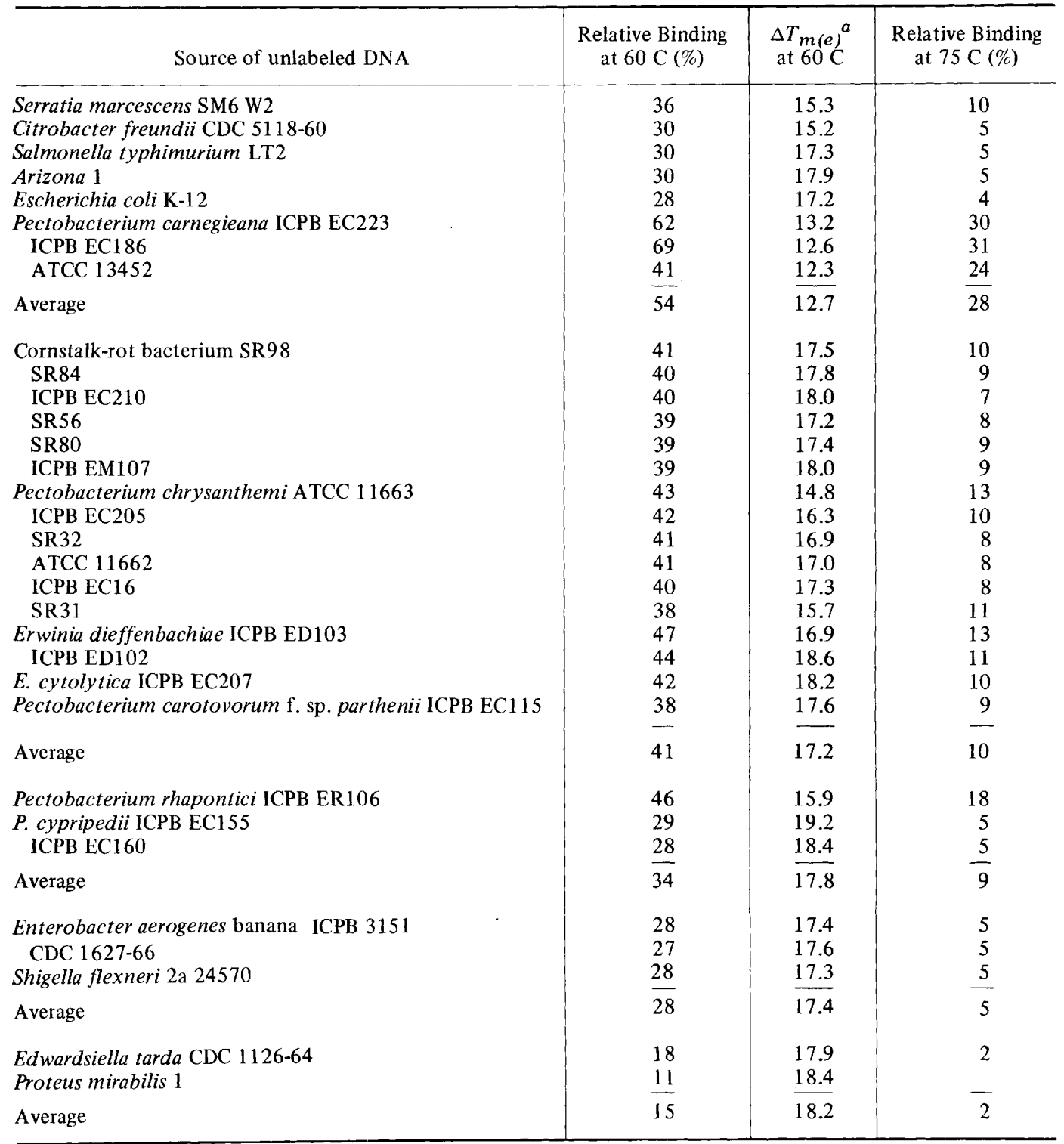

${ }^{a} T_{m(\mathrm{e})}$, Thermal elution midpoint; the temperature at which $50 \%$ of the DNA bound to hydroxyapatite (at the 60 or $75 \mathrm{C}$ incubation temperature) is eluted. $\Delta T_{m(e)}$ is the decrease in $T_{m(e)}$ between heterologous DNA reactions and the homologous $P$. carotovorum ATCC 495 reaction. The average extent of reassociation of $P$. carotovorum ATCC 495 DNA was $83 \%$ at both the 60 and $75 \mathrm{C}$ incubation temperatures. $P$. carotovorum DNA reassociated at $60 \mathrm{C}$ had an average $T_{m(e)}$ of $91.9 \mathrm{C}$.

Table 3 shows relatedness data obtained by using reference DNA from $P$. carnegieana ICPB EC186. P. carnegieana strains ICPB EC 186 and ICPB EC223 are essentially identical. DNA from $P$. carnegieana ATCC 13452 is only one-third related to DNA from ICPB EC186, and the related sequences contain $15 \%$ unpaired bases. At $75 \mathrm{C}$, relatedness between ICPB
EC186 and ATCC 13452 falls to $12 \%$. To rule out errors such as mislabeling or contamination in our handling of the culture, a new culture of P. carnegieana ATCC 13452 was obtained from the ATCC, and its DNA was tested. Results obtained with both cultures of ATCC 13452 are similar.

Relatedness between ICPB EC186 and mem- 
TABLE 3. Reassociation of DNA from Pectobacterium carnegieana ICPB EC186

\begin{tabular}{|c|c|c|c|}
\hline Source of unlabeled DNA & $\begin{array}{l}\text { Relative binding } \\
\text { at } 60 \mathrm{C}(\%)\end{array}$ & $\begin{array}{l}\Delta T_{m(e)^{a}} \\
\text { at } 60 \mathrm{C}\end{array}$ & $\begin{array}{l}\text { Relative binciing } \\
\text { at } 75 \mathrm{C}(\%)\end{array}$ \\
\hline $\begin{array}{l}\text { Pectobacterium carnegieana ICPB EC1 } 86 \\
\text { ICPB EC } 223 \\
\text { ATCC } 13452 \text { (old) } \\
\text { ATCC } 13452 \text { (new) }\end{array}$ & $\begin{array}{r}100 \\
99 \\
34 \\
32\end{array}$ & $\begin{array}{r}0.2 \\
15.3 \\
17.0\end{array}$ & $\begin{array}{r}100 \\
99 \\
12\end{array}$ \\
\hline $\begin{array}{l}\text { Erwinia aroideae ICPB EA144 } \\
\text { ATCC } 12286 \\
\text { E. atroseptica ICPB EA112 } \\
\text { ATCC } 7403 \\
\text { Pectobacterium carotovorum ICPB EC153 } \\
\text { ATCC } 495 \\
\text { ATCC } 25272 \\
\text { Bacillus oleraceae ICPB EO1 } \\
\text { Erwinia solanisapra ICPB ES101 } \\
\text { ATCC } 8061\end{array}$ & $\begin{array}{l}64 \\
64 \\
64 \\
65 \\
62 \\
62 \\
71 \\
63 \\
63 \\
57\end{array}$ & $\begin{array}{l}12.1 \\
11.0 \\
11.0 \\
11.2 \\
11.2 \\
12.1 \\
11.1 \\
12.8 \\
12.4 \\
12.2\end{array}$ & $\begin{array}{l}37 \\
41 \\
41 \\
38 \\
38 \\
35 \\
43 \\
40 \\
39 \\
32\end{array}$ \\
\hline $\begin{array}{l}\text { Pectobacterium cypripedii ICPB EC155 } \\
\text { ICPB EC } 160 \\
\text { Cornstalk-rot SR } 80 \\
\text { Pectobacterium rhapontici ICPB ER } 106\end{array}$ & $\begin{array}{l}28 \\
27 \\
37 \\
45\end{array}$ & $\begin{array}{l}17.1 \\
18.9 \\
18.0 \\
17.5\end{array}$ & $\begin{array}{r}7 \\
10 \\
14\end{array}$ \\
\hline $\begin{array}{l}\text { Erwinia nigrifluens } \mathrm{ICPB} \text { EN101 } \\
\text { E. salicis } \text { ICPB ES102 } \\
\text { E. rubrifaciens ICPB ER } 105 \\
\text { E. quercina ICPB EQ101 } \\
\text { E. amylovora ICPB EA } 169 \\
\text { ICPB } 178 \\
\text { ATCC } 7400 \\
\text { E. tracheiphila ATCC } 27004\end{array}$ & $\begin{array}{l}49 \\
47 \\
43 \\
33 \\
31 \\
26 \\
24 \\
21\end{array}$ & $\begin{array}{l}15.0 \\
17.2 \\
16.8 \\
16.5 \\
18.0 \\
15.5 \\
18.0 \\
18.3\end{array}$ & $\begin{array}{l}17 \\
14 \\
13\end{array}$ \\
\hline $\begin{array}{l}\text { E. herbicola ICPB EH103 } \\
\text { Xanthomonas uredovorus ICPB XU104 }\end{array}$ & $\begin{array}{l}30 \\
28\end{array}$ & $\begin{array}{l}18.9 \\
19.7\end{array}$ & 9 \\
\hline $\begin{array}{l}\text { Erwinia dissolvens ICPB ED114 } \\
\text { ICPB ED105 } \\
\text { ATCC } 23373 \\
\text { E. nimipressuralis ICPB EN1 } \\
\text { ATCC } 9912\end{array}$ & $\begin{array}{l}38 \\
31 \\
31 \\
33 \\
33\end{array}$ & $\begin{array}{l}13.8 \\
18.8 \\
19.1 \\
18.9 \\
19.6\end{array}$ & \\
\hline $\begin{array}{l}\text { Serratia marcescens SM6 W2 } \\
\text { Klebsiella pneumoniae } 2 \\
\text { K. ozaenae } \\
\text { Enterobacter cloacae } 165 \\
\quad 256-4 \\
\text { CDC } 1347-71 \\
\text { Salmonella typhimurium LT2 } \\
\text { Escherichia coli K-12 } \\
\text { E. aerogenes banana strain ICPB } 3151 \\
\text { CDC } 1627-66 \\
\text { E. hafniae CDC } 4360-67 \\
\text { Citrobacter freundii CDC } 460-61\end{array}$ & $\begin{array}{l}35 \\
34 \\
31 \\
32 \\
31 \\
31 \\
30 \\
29 \\
29 \\
28 \\
28 \\
26\end{array}$ & $\begin{array}{l}17.7 \\
17.6 \\
18.2 \\
18.2 \\
17.9 \\
18.0 \\
17.3 \\
18.7 \\
18.2 \\
18.3 \\
19.2 \\
18.4\end{array}$ & $\begin{array}{r}11 \\
9\end{array}$ \\
\hline
\end{tabular}

${ }^{a}$ Same as Table 2. The average extent of reassociation of $P$. carnegieana ICPB EC186 DNA was $86 \%$ at both 60 and $75 \mathrm{C}$ incubation temperatures. $P$. carnegieana ICPB EC186 DNA reassociated at $60 \mathrm{C}$ had an average $T_{m(e)}$ of $92.0 \mathrm{C}$. 
bers of the P. carotovorum group is 57 to $71 \%$, with 11 to $12 \%$ divergence in related sequences. Most of the related sequences remain stable at 75 C (32-43\% relatedness). As expected, these results are similar to those obtained in reciprocal reactions (Table 2) where $P$. carotovorum ATCC 495 was the reference organism.

Relative relatedness of $P$. carnegieana ICPB EC186 to other Enterobacteriaceae is significantly lower. In all cases, 14 to $20 \%$ unpaired bases are present, and only 7 to $17 \%$ relative binding occurs at $75 \mathrm{C}$. Among other pectobacteria, relatedness of ICPB EC186 is $45 \%$ to $P$. rhapontici, $37 \%$ to cornstalk-rot bacterium, and $28 \%$ to $P$. cypripedii. Related ness of ICPB EC186 to erwiniae is 21 to $49 \%$. E. nigrifluens, $E$. salicis, and $E$. rubrifaciens are the erwiniae most closely related to EC186 (43-49\%). ICPB EC186 shows $30 \%$ reaction with strains of Enterobacter agglomerans and 25 to $38 \%$ relatedness to other Enterobacteriaceae.

Surprisingly, except for two organisms in the $E$. agglomerans group (E. uredovora and $E$. cassavae), there are no type or neotype strains of Erwinia in the ATCC. To our knowledge, only $P$. cypripedii ICPB EC155 has been designated as a type strain (7). Therefore, it is possible that some of our data are based on strains that may be misidentified. We feel that this possibility is unlikely because the nature of these experiments is such that misidentified strains will be detected by lack of relatedness to validly identified strains. Furthermore, strains of $P$. carotovorum and of other designated species thought to be closely related to $P$. carotovorum (a total of 21 strains from three culture collections) exhibit a high level of DNA relatedness. Similar findings were obtained with the $P$. chrysanthemi group and cornstalk-rot organisms (Brenner and Kelman, manuscript in preparation). We are therefore confident that most of the strains used are correctly identified.

By using $P$. carotovorum ATCC 15713 as the reference strain in a previous study from this laboratory (6), related ness of $P$. carotovorum to erwiniae and to other Enterobacteriaceae was significantly lower at $60 \mathrm{C}$ than that observed in this study. The magnitude of the difference was mainly 10 to $15 \%$, although with certain organisms the differences were larger and quite striking. For example, $P$. carotovorum ATCC 15713 exhibited $15 \%$ relatedness to $E$. coli, $13 \%$ relatedness to $S$. typhimurium, and $18 \%$ relatedness to both $S$. marcescens and $P$. carnegieana ATCC 13452, whereas in the present study $P$. carotovorum ATCC 495 exhibited relatedness values to these organisms of $28,30,36$, and $41 \%$, respectively. Despite differences in relative binding, thermal stability of interspecies DNA duplexes was similar in both studies. P. carotovorum ATCC 495 is $90 \%$ related to $P$. carotovorum ATCC 15713. The $10 \%$ divergence in these strains may account for some of the quantitative binding differences. A difference in genome size could also explain these differences. For this to be true, the genome in ATCC 15713 would have to be substantially larger than that of ATCC 495.

Gardner and Kado (12) used direct DNADNA binding and competition experiments on nitrocellulose filters to determine relationships among erwiniae. They used formamide to decrease the $T_{m}$ of DNA and to allow DNA binding to occur at lower temperatures. In many cases, their data show quantitative differences in relatedness as determined by direct binding and by competition. Where similar strains are used, their data are in good agreement with the data presented here.

All pectobacteria are significantly related to other enteric bacteria. This core reaction, where tested, is $25 \%$ or greater except with Edwardsiella tarda and P. morganii (about 20\%), and $P$. mirabilis (about 10\%). E. tarda and P. mirabilis exhibit the same low level of relatedness with all genera of Enterobacteriaceae. There is no doubt that pectobacteria should remain in the family Enterobacteriaceae.

Five groups of pectobacteria are evident from this study. The $P$. carotovorum group and the $P$. carnegieana group are about $65 \%$ related. All other groups show less than $50 \%$ relatedness. The $P$. carotovorum group includes $P$. carotovorum, $E$. atroseptica, E. aroideae, E. solanisa$p r a$, and $E$. oleraceae. We cannot distinguish between these organisms. Strains of $P$. carnegieana form a second group. One strain, $P$. carnegieana ATCC 13452 , is not closely related to the other $P$. carnegieana strains. A third group of pectobacteria contains cornstalk-rot bacteria, $P$. chrysanthemi, E. dieffenbachiae, $E$. cytolytica, and $P$. carotovorum f. sp. parthenii. These organisms will be discussed in detail later (Brenner and Kelman, manuscript in preparation). Strains of $P$. cypripedii are a fourth group. Finally, $P$, rhapontici, which is not closely related to any other group, is placed in a fifth group.

Table 5 presents five classifications of the soft-rot erwiniae, or pectobacteria, along with guanine plus cytosine contents of their DNAs. Bergey's Manual of Determinative Bacteriology (2) lists nine species of soft-rot-producing erwiniae. E. ananas is not a soft-rot-producing species according to Waldee (17). Dye (8) has placed $E$. ananas in $E$. herbicola, which Ewing and Fife (11) have now classified as Enterobacter agglomerans. Graham reported E. citro- 
TABLE 4. Reassociation of DNA from Pectobacterium cypripedii ICPB EC155

\begin{tabular}{|c|c|c|}
\hline $\begin{array}{l}\text { Source of unlabeled } \\
\text { DNA }\end{array}$ & $\begin{array}{c}\text { Relative } \\
\text { binding } \\
\text { at } 60 \\
\mathrm{C}(\%)\end{array}$ & $\begin{array}{l}\Delta T_{m(e)}{ }^{a} \\
\text { at } 60 \mathrm{C}\end{array}$ \\
\hline $\begin{array}{l}\text { Pectobacterium cypripedii } \\
\text { ICPB EC } 155\end{array}$ & 100 & \\
\hline ICPB EC160 & 98 & +0.2 \\
\hline Erwinia aroideae ICPB EA144 & 24 & 18.9 \\
\hline ATCC 12286 & 21 & 18.6 \\
\hline E. atroseptica ICPB EA 112 & 24 & 18.2 \\
\hline ATCC 7403 & 24 & 18.0 \\
\hline $\begin{array}{l}\text { Pectobacterium carnegieana } \\
\text { ICPB EC186 }\end{array}$ & 22 & 19.0 \\
\hline ICPB EC 223 & 22 & 19.6 \\
\hline ATCC 13452 & 29 & 17.3 \\
\hline P. carotovorum ICPB EC153 & 25 & 18.0 \\
\hline ATCC 495 & 24 & 17.6 \\
\hline ATCC 15359 & 25 & 19.1 \\
\hline ATCC 25272 & 23 & 19.0 \\
\hline $\begin{array}{l}\text { Cornstalk-rot bacterium } \\
\text { SR80 }\end{array}$ & 30 & 18.9 \\
\hline Bacillus oleraceae ICPB EO1 & 24 & 19.0 \\
\hline $\begin{array}{l}\text { Pectobacterium rhapontici } \\
\text { ICPB ER } 106\end{array}$ & 24 & 19.5 \\
\hline $\begin{array}{l}\text { Erwinia solanisapra ICPB } \\
\text { ES101 }\end{array}$ & 27 & 18.4 \\
\hline ATCC 8061 & 21 & 18.1 \\
\hline E. amylovora ICPB EA169 & 33 & 17.5 \\
\hline ICPB EA 178 & 31 & 16.2 \\
\hline ATCC 7400 & 30 & 17.8 \\
\hline E. nigrifluens ICPB EN101 & 28 & 17.9 \\
\hline E. quercina ICPB EQ101 & 23 & 18.2 \\
\hline E. rubrifaciens ICPB ER 105 & 21 & 19.3 \\
\hline E. salicis ICPB ES102 & 25 & 17.9 \\
\hline E. tracheiphila ATCC 27004 & 26 & 17.9 \\
\hline E. herbicola ICPB EH103 & 42 & 14.3 \\
\hline $\begin{array}{l}\text { Xanthomonas uredovorus ICPB } \\
\quad \text { XU104 }\end{array}$ & 37 & 15.6 \\
\hline Erwinia dissolvens ICPB ED105 & 33 & 16.9 \\
\hline ICPB ED114 & 33 & 17.3 \\
\hline ATCC 23373 & 34 & 17.4 \\
\hline E. nimipressuralis $\mathrm{ICPB}$ EN1 & 29 & 18.2 \\
\hline ATCC 9912 & 31 & 17.0 \\
\hline Citrobacter freundii CDC 460-61 & 25 & 18.5 \\
\hline $\begin{array}{l}\text { Enterobacter aerogenes banana } \\
\text { strain ICPB } 3151\end{array}$ & 29 & 18.5 \\
\hline E. aerogenes CDC $1627-66$ & 31 & 18.3 \\
\hline E. cloacae yellow 165 & 31 & 17.5 \\
\hline CDC $1347-71$ & 32 & 17.8 \\
\hline yellow $256-4$ & 32 & 17.3 \\
\hline E. hafniae CDC $4360-67$ & 21 & 19.4 \\
\hline Escherichia coli $\mathrm{K}-12$ & 25 & 16.6 \\
\hline Klebsiella ozaenae & 33 & 17.1 \\
\hline K. pneumoniae 2 & 33 & 17.8 \\
\hline Serratia marcescens SM6 W2 & 31 & 17.2 \\
\hline Salmonella typhimurium $\mathrm{LT} 2$ & 24 & 17.2 \\
\hline
\end{tabular}

maculans to be identical to E. ananas (13). Two other organisms, E. dissolvens and E. nimipressuralis, are not considered to be Erwinia species by Dye (9), Graham (13), or Waldee (17). Waldee described $E$. dissolvens as a new species of Enterobacter (17), and Graham described $E$. nimipressuralis as resembling Enterobacter cloacae (13). Our data support these conclusions; both $E$. dissolvens and $E$. nimipressuralis are far more closely related to strains of Enterobacter cloacae (50-70\%) than to any other Enterobacteriaceae (Brenner, unpublished data).

$P$. carnegieana, according to Graham (13), is not a soft-rot-producing organism, and it resembles Enterobacter cloacae. Our data, from two of three strains, indicate substantial relatedness between $P$. carnegieana and $P$. carotovorum. The third strain we tested is not closely related to the other strains of $P$. carnegieana or to other pectobacteria. Ewing (personal communication) showed that $P$. carnegieana strains ICPB EC186 and ICPB EC223 are pectolytic and biochemically similar to other pectobacteria. In contrast, ATCC 13452 is not pectolytic and has biochemical characteristics typical of $K$. pneumoniae. In all probability, the confusion surrounding the status of $P$. carnegieana is due to a series of strains called $P$. carnegieana which are in reality $K$. pneumoniae. Before receiving the two pectolytic strains we sent to Ewing, he found all strains labeled $P$. carnegieana to be $K$. pneumoniae. Dye (personal communication) has also encountered two types of strains labeled $P$. carnegieana.

The remaining Erwinia species cited in Bergey's Manual are less controversial. $P$. carotovorum, $E$. atroseptica, and $E$. aroideae all produce soft rot. The question is whether they merit species status. Waldee (17) lists them as separate species, but Graham (13) and Dye (7) list them as varieties of $P$. carotovorum. We cannot distinguish between these organisms and feel that they and also $E$. solanisapra and $E$. oleraceae should be included in one species. $P$. chrysanthemi is listed as a variety of $P$. carotovorum by Dye (7) and by Graham (13), although the latter states that it may merit separate species status. $P$. chrysanthemi is certainly distinct from $P$. carotovorum based on DNA relatedness.

We find $P$. chrysanthemi to be indistinguishable from E. cytolytica, $P$. carotovorum f. sp. parthenii, and $E$. dieffenbachiae, and closely related to cornstalk-rot bacteria (Brenner and

\footnotetext{
${ }^{a}$ Same as Table 2 . The average extent of reassociation of $P$. cypripedii ICPB EC155 DNA was $90 \%$. The $T_{m(e)}$ of reassociated $P$. cypripedii ICPB EC155 DNA was $92.9 \mathrm{C}$.
} 


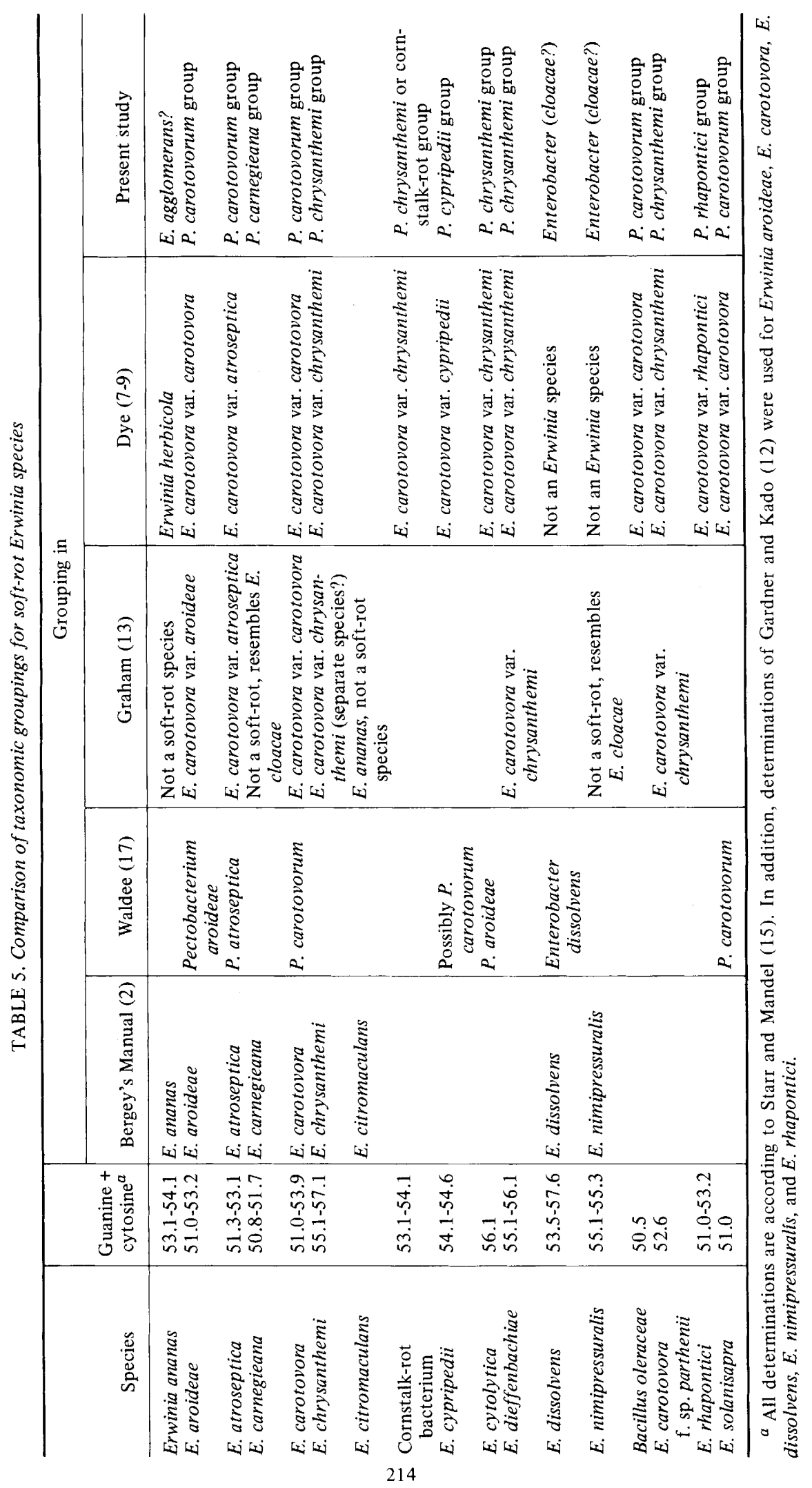


Kelman, manuscript in preparation). Graham (13) and Dye (7) agree that $E$. dieffenbachiae and $P$. carotovorum f. sp. parthenii are synonyms for $P$. chrysanthemi. E. cytolytica is considered as $P$. carotovorum by Waldee (17), Dye (7), and Graham (13). Relatedness of $E$. cytolytica to $P$. chrysanthemi is supported by the higher guanine plus cytosine content present in their DNA as compared with DNA from $P$. carotovorum (15, Table 5). Dye has placed the cornstalk-rot organisms with $P$. chrysanthemi (7). P. cypripedii and $P$. rhapontici are not included in the current Bergey's Manual (2). Waldee (17) states that $P$. cypripedii is possibly similar to $P$. carotovorum. Dye (7) treats both organisms as separate varieties of $P$. carotovorum. Our data show that these organisms are distinct from each other and from other pectobacteria.

Neither $P$. cypripedii nor $P$. rhapontici produces pectinase on pectate media, and these organisms do not produce soft-rot diseases. Furthermore, neither of these organisms is significantly more related to pectobacteria than to other Enterobacteriaceae. Despite these facts, we recommend their inclusion in pectobacteria because they are most biochemically similar to pectobacteria $(7,17)$. Failure to produce pectinase and failure to cause soft-rot disease are not unique to these species. At 22 to $25 \mathrm{C}, 25 \%$ of 90 pectobacteria (mainly $P$. carotovorum) did not produce pectinase within $48 \mathrm{~h}$, and at $37 \mathrm{C}$ only $42 \%$ of these strains produced pectinase within $48 \mathrm{~h}(10)$.

Even if one accepts the five groups of pectobacteria as shown by DNA relatedness, classification is complicated by additional considerations. One of these concerns phytopathogenicity and host range. Phytopathogenicity can be lost by simple mutation (for example, a single base mutation that affects pectinase activity). Since phytopathogenicity and host range are of critical interest to the plant pathologist, he requires a means of differentiation based on these parameters. DNA relatedness of pectobacteria to erwiniae and other Enterobacteriaceae is sometimes greater than relatedness between groups of pectobacteria. For instance, $P$. carotovorum shows significantly higher relatedness to $E$. nigrifluens, $E$. salicis, and E. rubrifaciens than to $P$. cypripedii (see Tables 2, 3 and 4 for further examples) despite the fact that the pectobacteria are biochemically much closer to each other than they are to erwiniae.

In the absence of one perfect system of taxonomy that satisfies the bacteriologist, the plant pathologist, and the evolutionist, one can either have separate taxonomies or make certain compromises. Waldee's (17) system of two genera in the tribe Erwinia separates organisms by biochemistry and phytopathogenicity. Both Graham (13) and Dye (7) attack the problems by severely restricting the number of species. They recognize $E$. carotovora as the only soft-rot species. Phytopathogenicity is dealt with at the level of variety, for example, E. carotovora var. carotovora, E. carotovora var. chrysanthemi, etc.

We feel that a combination of these approaches provides a means for obtaining one taxonomy for Erwineae that can be embraced by and be meaningful to all concerned. Our proposals are as follows: (i) maintain the tribe Erwineae as it now stands in Bergey's Manual (2); (ii) reserve the genus Erwinia for species that produce wilts or blight diseases and whose biochemical characteristics are similar to those of $E$. amylovora, the type species; (iii) reserve the genus Pectobacterium for soft-rot-producing organisms and other organisms whose biochemical characteristics are similar to those of $P$. carotovorum, the type species; (iv) on the basis of morphological and biochemical characteristics and similarities in DNA, transfer Erwinia carnegieana, E. chrysanthemi, and $E$. cypripedii to the genus Pectobacterium; (v) place yellow-pigmented "erwiniae" in Enterobacter agglomerans unless DNA relatedness data taken together with biochemical characteristics show them to belong more properly in another group; (vi) require host range patterns before admitting additional organisms to either Erwiniae or Pectobacterium; (vii) use infrasubspecific terms such as "forma specialis" or "variety" to designate host range or other important traits; and (viii) remove $E$. nimipressuralis and $E$. dissolvens from Erwinia. These organisms are more properly classified in the genus Enterobacter as E. cloacae or in one or two additional species $(9,13,17$; Brenner, unpublished data).

Following these proposals, the genus Pectobacterium would presently consist of five species: $P$. carotovorum, $P$. chrysanthemi, $P$. carnegieana, $P$. cypripedii, and $P$. rhapontici. Infrasubspecific forms would be recognized as warranted.

\section{REPRINT REQUESTS}

Address requests for reprints to: Dr. Don J. Brenner, Division of Biochemistry, Walter Reed Army Institute of Research, Washington, D.C. 20012. 


\section{LITERATURE CITED}

1. Berns, K. I., and C. A. Thomas. 1965. Isolation of high molecular weight DNA from Hemophilus influenzae. J. Mol. Biol. 11:476-490.

2. Breed, R. S., E. G. D. Murray, and N. R. Smith. 1957. Bergey's manual of determinative bacteriology, 7th Ed. The Williams \& Wilkins Co., Baltimore.

3. Brenner, D. J., G. R. Fanning, K. E. Johnson, R. V. Citarella, and S. Falkow. 1969. Polynucleotide sequence relationships among members of the Enterobacteriaceae. J. Bacteriol. 98:637-650.

4. Brenner, D. J., G. R. Fanning, A. Rake, and K. E. Johnson. 1969. A batch procedure for thermal elution of DNA from hydroxyapatite. Anal. Biochem. 28:447-460.

5. Brenner, D. J., G. R. Fanning, F. J. Skerman, and S. Falkow. 1972. Polynucleotide sequence divergence among strains of Escherichia coli and closely related organisms. J. Bacteriol. 109:953-965.

6. Brenner, D. J., G. R. Fanning, and A. G. Steigerwalt. 1972. Deoxyribonucleic acid relatedness among species of Erwinia and between Erwinia species and other bacteria. J. Bacteriol. 110:12-17.

7. Dye, D. 1969. A taxonomic study of the genus Erwinia. II. The "Carotovora" group. N.Z.J. Sci. 12:81-97.

8. Dye, D. 1969. A taxonomic study of the genus
Erwinia. III. The "Herbicola" group. N.Z.J. Sci. 12:223-236.

9. Dye, D. 1969. A taxonomic study of the genus Erwinia. IV. "Atypical" erwinias. N.Z.J. Sci. 12:833-839.

10. Edwards, P. R., and W. H. Ewing. 1972. Identification of Enterobacteriaceae, 3rd ed. Burgess Publishing Co., Minneapolis, Minn.

11. Ewing, W. H., and M. A. Fife. 1971. Enterobacter agglomerans. Publication of the Center for Disease Control, Atlanta, Ga.

12. Gardner, J. M., and C. I. Kado. 1972. Comparative base sequence homologies of the deoxyribonucleic acids of Erwinia species and other enterobacteria. Int. J. Syst. Bacteriol. 22:201-209.

13. Graham, D. C. 1964. Taxonomy of the soft rot coliform bacteria. Annu. Rev. Phytopathol. 2:1343.

14. Laird, C. D., B. L. McConaughy, and B. J. McCarthy. 1969. On the rate of fixation of nucleotide substitutions in evolution. Nature (London) 224:149-154

15. Starr, M. P., and M. Mandel. 1969. DNA bast composition and taxonomy of phytopathogenic and other enterobacteria. J. Gen. Microbiol. 56:113-123.

16. Von Graevenitz, A. 1970. Erwinia species isolates. Ann. N.Y. Acad. Sci. 174:436-443.

17. Waldee, E. L. 1945. Comparative studies of some peritrichous phytopathogenic bacteria. Iowa State J. Sci. 19:435-484. 